“Transfer” XV: 1-2 (2020), pp. 502-561. ISSN: 1886-554

TRADUCCiÓ Al CATALÀ DE MIĘDZY NAMI DOBRZE JEST (ACTE 1), DE DOROTA MAStOWSKA

Pau Freixa (ORCID: 0000-0002-1906-8983)

Universitat de Barcelona

A continuació presentem la traducció al català, realitzada directament del polonès per Pau Freixa, de Między nami dobrze jest (Acte 1), de l'escriptora Dorota Masłowska. En primer lloc, després d'una breu presentació, s'inclou el text original, i a continuació la traducció.

Dorota Masłowska està considerada una de les veus més interessants de la literatura polonesa actual. La seva novel-la Wojna polsko-ruska pod flaga biało-czerwona (publicada el 2005 en castellà com a Blanco nieve, rojo Rusia per l'editorial Mondadori), amb el seu flux de consciència narcotitzat i vulgar, un discurs fragmentari i eclèctic -fruit de la fragmentació i eclecticisme propis de la societat post-comunista-, i un humor desenfrenat fruit d'un intens joc amb el llenguatge, commocionà les lletres poloneses quan aparegué el 2002. L'autora tenia 18 anys quan la va escriure. Avui en dia es considera que l'obra de Masłowska dona el tret de sortida a la literatura post-moderna a Polònia.

El drama que presentem aquí és el segon de l'autora. Es tracta d'un encàrrec del prestigiós teatre TR Warszawa. Ha estat posat en escena i portat a la pantalla pel director Grzegorz Jarzyna i posteriorment ha estat traduït i representat a molts països del món occidental i de l'Europa Oriental. A través dels desencontres constants de tres dones, representants de tres generacions, que no troben un llenguatge comú perquè viuen en realitats diferents, es dibuixa una gran al-legoria sobre el destí dels polonesos, marcats encara pels traumes de la Segona Guerra Mundial i l'ocupació 
“Transfer” XV: 1-2 (2020), pp. 502-561. ISSN: 1886-554

soviètica. Entre nosaltres tot va bé apareixerà aviat en traducció al castellà de Pau Freixa (conjuntament amb la també divertidíssima -i amarga- tragicomèdia Dwoje biednych Rumunów mówiacych po polsku, [Dos pobres romanesos que parlaven polonès]) publicat per la editorial La Uña Rota. 
“Transfer” XV: 1-2 (2020), pp. 502-561. ISSN: 1886-554

Między nami dobrze jest

\section{Dorota Masłowska}


“Transfer” XV: 1-2 (2020), pp. 502-561. ISSN: 1886-554

Dla mojej Mamy

z okazji 25-lecia

na jednym świecie.

(i oczywiście dla Agaty) 
“Transfer” XV: 1-2 (2020), pp. 502-561. ISSN: 1886-554

OSOBY:

MAŁA METALOWA DZIEWCZYNKA

HALINA

BOŻENA

OSOWIAŁA STARUSZKA NA WÓZKU INWALIDZKIM

MEZŻCZYZNA

AKTOR

PREZENTERKA

EDYTA

MONIKA 
“Transfer” XV: 1-2 (2020), pp. 502-561. ISSN: 1886-554

\section{Akt 1}

\section{SCENA 1}

Stary wielokondygnacyjny budynek ludzki w Warszawie. Mieszkanie jednopokojowe. Dwie pary drzwi - jedne wychodza na podwórko z pojemnikami na odpady wtórne, zza drugich dochodzi cały czas toaletowy szum, wodne bełkoty, ciurkanie rur. Okno, za którym przetacza się caly czas $w$ bezpośredniej bliskości dzika, zoszystkożerna karuzela wielkiego miasta ze swoimi tramwajami, samochodami, klaksonami $i$ przelatujacymi po niskim niebie samolotami, od których drży $w$ barku butelka ze zwietrzatym Ciociosanem, drża misterne piramidy obitych $i$ oblepionych resztkami żywności garnków i garnuszków na kuchence, trzęsie się obraz $w$ wiecznie wtaczonym telewizorze $i$ syczy $i$ spina sie żarówka $w$ żyrandolu. Wnętrze sprawia cały czas wrażenie zbudoicanego na pękajacej ziemi albo spychanego spycharka, Mata Metalowa Dziewczynka $w$ marynarskim ubranku $i$ dziko prężaca się kokarda w rzadkich metalicznych włoskach i jej babcia, Osowiała Staruszka na wózku inwalidzkim ciagnaca za soba po wyktadzinie splatane kable warkoczy albo pajęczyn, sq w nim jak pasażerki tonacego statku - zawieszone pomiędzy panika a nuda, bezmyślna aktywnościa a bezmyślna stagnacja, klaustrofobia a lękiem przestrzeni, z charakterystyczna dla osób skazanych na swoje towarzystwo niejasnościa, czy bardziej gonia się, czy przed soba uciekaja, czy zmęczone jednym i drugim trwaja w bezruchu. Pomiędzy ich naprzemiennymi napadami stuporu $i$ nadpobudliwości matka Dziewczynki, Halina, wykonuje $z$ niewzruszeniem automatycznego zwierzęcia pociagowego 
automatyczne czynności gospodarcze, a teraz akurat wychodzi wyrzucić śmieci.

OSOWIAŁA STARUSZKA NA WÓZKU INWALIDZKIM: Ech, pamiętam dzień, w którym wybuchła wojna.

MAŁA METALOWA DZIEWCZYNKA: Co wybuchło?

OSOWIAŁA STARUSZKA NA WÓZKU INWALIDZKIM: Wojna. Byłam wtedy młodą śliczną dziewczyną, a twarz miałam jak wiosna, serce tłukło się w młodej piersi jak slowiczek schwytany w...

MAŁA METALOWA DZIEWCZYNKA: W słoiczek.

OSOWIAŁA STARUSZKA NA WÓZKU: Jeszcze wtedy chodziłam na nogach, Boże, jak ja chodziłam.

MAŁA METALOWA DZIEWCZYNKA: Eee, przesadza babcia z tym chodziłam i chodziłam.

OSOWIAŁA STARUSZKA: A tak, chodziłam, pamiętam że...

MAŁA METALOWA DZIEWCZYNKA: Tyle babcia chodziła, to się chyba babcia nachodziła. Teraz babcia sobie może wreszcie gdzieś nie pójść. O Jezu, ja to jakbym była babcią, to bym sobie nie poszła, oj nie poszła. Do szkoły, na angola i jeszcze by się znalazło $\mathrm{w}$ parę miejsc.

OSOWIAŁA STARUSZKA: W te $\mathrm{i}$ we wte, w te i we wte. Przed wojną to się chodziło że aż hej. Do kina, na wafle, na ptifury, nad rzekę. Po piasku, po ziemi, nad rzekę. Po trawie, po fiołkach pu- 
“Transfer” XV: 1-2 (2020), pp. 502-561. ISSN: 1886-554

szystych, nad rzekę, w upalne dni, gdy jej gruba, czysta, porznięta promieniami słońca jak jaka karafka tafla...

MAŁA METALOWA DZIEWCZYNKA: Jaką znowu rzekę?

STARUSZKA: Jak to? Nad Wisłę.

MAŁA METALOWA DZIEWCZYNKA: Nad tę gnojówę? O Jezu.

STARUSZKA: Jaką gnojówę? Tu, nad Wisłę. Tylko saboty na nogi, kawałek chleba w rękę i dalejże. Kąpać się, opalać, marzyć, śnić sen najpiękniejszy, najświętszy sen młodości, czysty jak łzy, co po policzkach..

MAŁA METALOWA DZIEWCZYNKA: A co to jest „chleba"? Nie nie, żartowałam. Też przepadam kąpać się w Wiśle, to ponaczczasowa przyjemność. Zawsze jak wychodzę na brzeg, raźno parskając benzyną, to mam odrę, dur brzuszny i zatrucie kadmem, i nie żyję, więc dostaję zwolnienie rekalskie i nie muszę już chodzić do szkoły.

STARUSZKA: Płotki łowiliśmy, drobne, dzikie, tak się targały raptusy, srebrną tłustą łuską brukając nam dłonie.

MAŁA METALOWA DZIEWCZYNKA: Co babcia mówi, my też nieraz łowimy preski. W znaczeniu zgnite kondony. A jak uciekają, a jak się wyrywają! Chłopaki się śmieją, a mnie to krew zalewa, jak sobie uświadamiam, ile szczwanych oportunistycznych potencjalnych Polaczków każdego dnia wywija się od istnienia. 
“Transfer” XV: 1-2 (2020), pp. 502-561. ISSN: 1886-554

OSOWIAŁA STARUSZKA: Wszyscy mówili że Hitler, ojciec mówił, że ten Hitler...

MAŁA METALOWA DZIEWCZYNKA: A jak się wyrywają! Myślą chyba, że Wisła w połowie Polski skręca i płynie prosto do Ameryki i że tam się urodzą ze stupięćdziesięciudolarówką w jednej ręce $\mathrm{i}$ trzystapiętnastodolarówką $w$ drugiej, a my tu będziemy sami się użerać na tym kartoflisku. Urodzą się, urodzą, z miotłą i szufelką, i ogryzioną palką od świątecznego indyka, ze śmietnika! A raczej nie urodzą, bo my ich chlaps i ten...

OSOWIAŁA STARUSZKA: A kto tam wierzył w jakiegoś Hitlera, młody był człowiek, serce szarpało się w piersi... szarpało się jak złapany...

MAŁA METALOWA DZIEWCZYNKA: ...kondon w słoiczek!

Do mieszkania, starannie wycierając pantofle, wchodzi Halina $z$ bim-bajacym smętnie opróżnionymi ze śmieci wiaderkiem. Zadowolona, starannie wyciera pantofle domowe $w$ wycieraczke $i$ wiesza kluczyk na haczyk. Może przynieść też z piwnicy węgiel, ogórki konserzuowe albo tak przydatne zima przy przywożeniu pościeli z magla saneczki dziecięce, ale najważniejsze, że pod pacha przynosi znaleziony właśnie skarb - wychachmęcony z kubła z makulatura magazyn kobiecy, mocno już przez kogoś przeczytany.

HALINA: Jaki słoiczek? Co to znowu za słowa?

MAŁA METALOWA DZIEWCZYNKA: Mama to taka oburzona, jakbym została poczęta drogą usiądnięcia mamy na brudnym fotelu w PKP Nieintercity. 
“Transfer” XV: 1-2 (2020), pp. 502-561. ISSN: 1886-554

Halina kręci się koło swojego królestwa - kuchenki po sufit zastawionej festiwalem różnych osmalonych $i$ ocharchanych garnuszków, wydartych z kalendarzy przepisów kucharskich, gazetek z Tesco, starannie zachowanych ulotek szkót językowych $i$ etykietek od konserw, stert umytych starannie kubeczków po jogurtach. W ślad za nia postepuje, takomie zagladajac jej przez ramię i śliniąc się, Mała Metalowa Dziewczynka, usitująca dostać się do cukierniczki. Halina bije ja po brudnych łapach.

HALINA: Obiad jadłaś?

MAŁA METALOWA DZIEWCZYNKA: A co jest na obiad?

HALINA: A suche pierdo z octem.

MAŁA METALOWA DZIEWCZYNKA (unoszac pokrywkę jakiegoś garnka): A suche pierdo, moje ulubione. A co tak wstrętnie śmierdzi?

HALINA (wyrywajac jej garnek $i$ kategorycznym gestem zamykajac lodówkę): Zostaw, to ja sobie odgrzeje na kolację.

OSOWIAŁA STARUSZKA: Aż do Warszawy wkroczyli Niemcy. Ja tylko w sukience, tylko $\mathrm{z}$ torebką, w torebce tylko...

MAŁA METALOWA DZIEWCZYNKA: Niemcy, Niemcy, coś słyszałam o jakichś Niemczech... O Jezu, wiem, to ci, co tak jodłują!

OSOWIAŁA STARUSZKA: Ja tylko z torebką, tylko w tej sukience $\mathrm{w}$ różyczki... 
“Transfer” XV: 1-2 (2020), pp. 502-561. ISSN: 1886-554

MAŁA METALOWA DZIEWCZYNKA: Chyba w zgnite... Znaczy w suszone!

OSOWIAŁA STARUSZKA: ...wracałam znad Wisły, bo dzień był całkiem upalny, z oczami jeszcze wciąż zbłękitniałymi od patrzenia w jej senną, chłodną, mydlaną, czystą...

MAŁA METALOWA DZIEWCZYNKA: ....brudną, ciepłą, zielonkawą, spienioną, jadowitą taflę tej gnojowy...

OSOWIAŁA STARUSZKA: ...gdy aż tu nagle...

MAŁA METALOWA DZIEWCZYNKA: Gdy aż tu nagle bum.

OSOWIAŁA STARUSZKA: Słucham?

MAŁA METALOWA DZIEWCZYNKA: Dym, płomienie, ogień, widziała babcia?

OSOWIAŁA STARUSZKA: Co widziałam?

MAŁA METALOWA DZIEWCZYNKA: No jak się palił?

OSOWIAŁA STARUSZKA: Co się pali?

MAŁA METALOWA DZIEWCZYNKA: ROWER. Rower.

OSOWIAŁA STARUSZKA: Jaki rower? 
MAŁA METALOWA DZIEWCZYNKA: A nie wiem. Strasznie było słychać palącym się rowerem, ja czego jak czego, ale tego charakterystycznego swądu nie pomylę z niczym.

OSOWIAŁA STARUSZKA: Nie, nie widziałam.

MAŁA METALOWA DZIEWCZYNKA: A ja widziałam.

Niezwruszona rodzinnymi tiiesnaskami Halina, potrzaskawszy trochę dla animuszu pokrywkami od garnków, ściera ze stotu dłonia niewidzialne okruchy, wyciera ręce $w$ sweter $i$ wzdychajac $w$ kierunku niebios zabiera się do lektury świeżo zdobytego magazynu.

MAŁA METALOWA DZIEWCZYNKA: Co tam mama ma? Nowa gazetka cenowa?

HALINA: A to magazyn. „NIE DLA CIEBIE". Był w kuble z makuraturą. Za darmo, więc mówię: a kupię, a co, a stać mnie.

MAŁA METALOWA DZIEWCZYNKA: Nawet niezły.

HALINA: Z kwietnia zeszłego roku. W sam raz nie dla mnie.

MAŁA METALOWA DZIEWCZYNKA: Nawet krzyżówkę ma mama od razu rozwiązaną.

HALINA: Nie muszę rozwiązywać, tylko od razu mam hasło. Wiosenne tete a tete.

MAŁA METALOWA DZIEWCZYNKA: Mama pokaże. Wiosenne tete a tete... Chwilka... Wiosenna macanka nad gnojówką? 
“Transfer” XV: 1-2 (2020), pp. 502-561. ISSN: 1886-554

HALINA: Babcia już nie jadła obiadu?

MAŁA METALOWA DZIEWCZYNKA: Babciu, nie jadłaś już obiadu?

OSOWIAŁA STARUSZKA: A co było?

HALINA: Leczo.

MAŁA METALOWA DZIEWCZYNKA: Leczo. Różne takie flupsy z papryką i spermą węgierskich kosmitów. Zobacz również: zupa tygodnia, zupa miesiąca, niemarnowanie, II wojna światowa, głód.

OSOWIAŁA STARUSZKA: A nie nie nie, to nie jadłam.

MAŁA METALOWA DZIEWCZYNKA: Babcia nie jadła.

HALINA: Dlaczego to?

MAŁA METALOWA DZIEWCZYNKA: A ja wiem? Najpewniej się odchudza, ja też się odchudzam.

HALINA: A czy babcia już dzisiaj nigdzie nie była?

MAŁA METALOWA DZIEWCZYNKA: Ja, ja, ja! Ja nie zabrałam nigdzie babci.

HALINA: No to dobrze, to ja już nie musze jej nigdzie nie zabierać, czego i tak bym nie zrobiła, bo wrócę dziś z pracy po 23 .

MAŁA METALOWA DZIEWCZYNKA: W końcu cały dzień siedzi babcia w domu bez windy, do nikogo ust otworzyć, więc jak 
“Transfer” XV: 1-2 (2020), pp. 502-561. ISSN: 1886-554

wracam ze szkoły i aż do wieczora siedzę przed telewizorem, to nie mam czasu tej starej brukwi jeszcze gdzieś wozić! Rączo furgotały na wietrze moje warkoczyki, gdy tak sobie nie szłyśmy jesiennym parkiem, ona opowiadała mi te swoje pyszne historie, jak pojechała na ten obóz koncentracyjny. Moim zdaniem trochę zżyna $\mathrm{z}$ Czterech pancernych i psa i Alb Allo, ale niech jej tam. W końcu jest postmodernizm.

HALINA: Co ty znów wygadujesz? Co to za słowa?

MAŁA METALOWA DZIEWCZYNKA: Też nie znam, dopiero ściągnęłam $\mathrm{z}$ internetu.

No $\mathrm{i}$ tak nie spacerowałyśmy sobie $\mathrm{w}$ najlepsze $\mathrm{w}$ tę $\mathrm{i}$ we wtę po ozłoconych jesienią alejkach, gdy ni stąd ni zowąd przyczepił się do nas pewien natręt. Jak myślę, był Niemcem, bo był kurturalny i nawet ukłonił się, stuknął obcasami i mówi tak: Dzień dobry, moje nazwisko Arzheimer, ale to jego nazwisko to całkiem wyleciało mi z głowy... No jakże on to tam... no zapomniałam... czy ja już zupełnie tracę głowę? Takie znane nazwisko na A... Jakże to... No nieważne. W każdym razie ledwie zapomniałam nazwisko tego, już pojawił się następny, też zapukał, bardzo kurturalny, ubrany w taką perukę i mówi: jestem tym znanym filozofem niderlandzkim, tym, no jak mu tam, no, ten co przeciwstawił się dualizmowi kartezjańskiemu... No SKLEROZA. No właśnie. Jak nie zaczęli mącić, jak nie zaczęli kręcić, uznałam że moja dłuższa obecność $\mathrm{w}$ babci braku pokoju jest zbędna a wręcz krępująca, więc nie chcąc im przeszkadzać, poszłam do swojego braku pokoju i aż do wieczora siedziałam tu razem $\mathrm{z}$ wami przed telewizorem.

Halina przybiera dogodna pozycje osoby czytajacej gazete $i$ jednocześnie ogladajacej telewizję, co utrudnia jej patętająca się wszędzie na swoim wózku Staruszka. 
“Transfer” XV: 1-2 (2020), pp. 502-561. ISSN: 1886-554

HALINA: E, ojciec szklorz, matka szyba. Mamie to się ciągle zdaje, że jest przezroczysta. Niech mama lepiej zje flupsy z papryką. Dla kogo ich nie ugotowałam, tylko przelewałam cały tydzień $\mathrm{z}$ garka $\mathrm{w}$ garnek?

MAŁA METALOWA DZIEWCZYNKA: Najpewniej się odchudza, nie chce być już taka wychudła, tylko przezroczysta.

OSOWIAŁA STARUSZKA: Ja chodziłam! Przed wojną to się chodziło, że aż hej, to się biegało. Do kina, na wafle, na ptifury, nad rzekę.

MAŁA METALOWA DZIEWCZYNKA: No jak babcia będzie jeść ciągle te wafle i inne kogle-mogle, to gratuluję. Nigdy się babcia nie odchudzi.

OSOWIAŁA STARUSZKA: Po piasku, po ziemi, nad rzekę. Tylko kawałek chleba w rękę i dalejże...

MAŁA METALOWA DZIEWCZYNKA: Niech babcia zapomni o chlebie, zwłaszcza biały pszenny - tuczy. I ważny jest ruch. Jak babcia będzie tak tylko siedzieć na tym wózku inwalidzkim, to babcia się nigdy nie odchudzi, musi babcia więcej jeździć, a przynajmniej sama się pchać. Cicho, bo ktoś pukał. Puk puk.

OSOWIAŁA STARUSZKA: Kto tam?

MAŁA METALOWA DZIEWCZYNKA: Otworzę, sprawdzę... A nie... Myślałam, że to przyszła II wojna światowa.

HALINA: Co ty znowu opowiadasz!? 
“Transfer” XV: 1-2 (2020), pp. 502-561. ISSN: 1886-554

MAŁA METALOWA DZIEWCZYNKA: Przysięgam. No nic, widocznie przelatywały po prostu jakieś modele samolotów. 
“Transfer” XV: 1-2 (2020), pp. 502-561. ISSN: 1886-554

\section{SCENA 2}

Mieszkanie $i$ wszystko tak jak wcześniej. Staruszka w stuporze, Dziewczynka bawi się znudzona kogucikiem na patyku. A jednak w pewnym momencie, oceniwszy tę czynność jako nietwórcza, zaczyna swoim patykiem pchać po mieszkaniu babcię. Halina, trochę poirytowana ich przepychankami, trochę już na nie impregnowana, zagłębia się $w$ lekturze swojego magazynu, jednocześnie z cyrkowa wprawa łapiac spadajace z szaf i półek przedmioty. Po podwórku moga przechodzić jacyś ludzie wrzucajacy śmieci do odpowiednich pojemników. Pomiędzy nimi może czaić się monstrualnie gruba Bożena, jak komandos ukrywajaca się przed ich spojrzeniami za niemogacymi ukryć jej obelżywie wielkiego ciała pojemnikami. Osowiałej Staruszce udaje się wynoaćz kociokwiku zabawy $i$ pośpiesznie zamyka się na kluczyk w toalecie wśród kojacych ciurkań wody.

HALINA: Już zakwitły pierwiosnki i pełną parą nadeszła wiosna, kusząc nas swoją piękną aurą.

Chętniej wybierasz się na dotleniający spacer, do łask wraca też rower. Chętniej nie wybierasz się na dotleniający spacer, do łask nie wraca też rower, którego nie posiadasz. Słoneczne popołudnia sprzyjają aktywności fizycznej i spotkaniom $z$ przyjaciółmi, z którymi się nie spotykasz, bo ich nie masz i wspólny wyjazd z miasta i wypad $\mathrm{z}$ restauracji, if you know what I mean. Najwyższy czas na porządki w wiosennej garderobie!

$\mathrm{Na}$ wieszak nie wędrują szarości, brązy, grube rajstopy, ciężkie swetry, palta i jesionki.

Chętniej nie wkładasz też tych lekkich sukienek, których nie masz i cienkich rajstop, których również nie masz. Na pewno nie masz też lżejszych żakietów, ale na ten jeden co masz, to na 
“Transfer” XV: 1-2 (2020), pp. 502-561. ISSN: 1886-554

pewno jesteś zbyt gruba. Nie szkodzi. Oto nasze zeszłoroczne propozycje, które nie pozwolą ci zlądować twardo na marginesie wszystkiego z ręką w nocniku wiosennych trendów.

MAŁA METALOWA DZIEWCZYNKA: Trochę przetrzepać $\mathrm{z}$ moli, trochę popryskać dezodoryzantem, trochę wyprać, trochę nie wyprać, trochę w ogóle nie wyprać, nie wyjąć z szafy i chodzić w tym, w czym się spało i spać w tym, w czym się chodzi, trochę otrzepać, trochę w ogóle nie mieć wcale i gotowe! Wysiłek żaden, a i efekt proporcjonalnie nie większy.

HALINA: Spódnica - Tesco, 28 złotych. Plama z tłuszczu doda zagadkowości. Podkoszulka - z szafy, przetarta na cycach. Szarości, brązy i urynowa żółć, tłuste plamy i przecierki, to hity tego sezonu jak i każdego innego sezonu. Plamy potu. Nasz trick - prędzej niż później pojawią się same. Skarpetyjnęskie - Stadion Dziesięciolecia, 17 par 10 złotych. Buty -skaj. „Wszystko po pięć złotych", 12 złotych. Torebka - siatka plastikowa. Złoty pięćdziesiąt, Lidl. Duża i pakowna, pojemność - 10 kilo kartofli, 5 butelek octu, łapy kurze, wczorajszy numer bezpłatnej gazety „Metro", ale zmieści się jeszcze niewielka portmonetka. Można myć w zlewie.

MAŁA METALOWA DZIEWCZYNKA: Zeszło wiosenne zabiegi na poszarzoną zimą i zniszczoną papierosami, niewłaściwym odżywianiem i chorobą wieńcową cerę.

HALINA: Twarz umyj mydłem i posmaruj kremem Nivea albo zwykłą margaryną. Świetnie zrobi też tarcie ręcznikiem.

MAŁA METALOWA DZIEWCZYNKA: Nasza porada: swojego kremu Nivea, aby starczył ci na dłużej, nie używaj. 
“Transfer” XV: 1-2 (2020), pp. 502-561. ISSN: 1886-554

HALINA: Jednej połowy włosów nie umyj swoim zwykłym szamponem, a drugiej połowy też. Nasz trick: im częściej tego nie robisz, tym lepiej widać, że ich nie masz, dłużej też utrzymają niepokojący zapach szafki na buty i przepoconej słoninki. Kwiecień zeszłego roku to nareszcie okazja by wiosenne słońce nie igrało $\mathrm{w}$ ich smętnych tłustych kosmykach.

Odczekawszy swoje, Staruszka nieporadnie pcha się z powrotem do mieszkania, za nia odgłos spuszczanej toody.

MAŁA METALOWA DZIEWCZYNKA: Wózka nie oliw przejmujące skrzypienie doskonale da innym do zrozumienia, że właśnie wjechałaś i że pitoleniu zaraz nie będzie końca...

HALINA: No popatrz mamo, a głowę bym dała sobie uciąć, że mama sobie tam siedzi, bo tam ma święty spokój i dalibóg, nie pomyliłam się (energicztiym gestem, wciąż zaczytana, przesuwa wózek Staruszki konsekwentnie tak, by nie zasłaniał jej telewizora).

MAŁA METALOWA DZIEWCZYNKA (do Staruszki, udajac, że téz $c z y t a)$ : W kwietniu zeszłego roku wszystko będzie jak było. Otrzymasz tajemniczy list, to może być upomnienie z gazowni! Dni znaczące: piętnasty. Wysyrn^ęi się kulki nample. Dni nieznaczące: wszystkie pozostałe. Twój szczęśliwy kolor: przezroczysty. Twój szczęśliwv kamień: kamień nerkowy.

HALINA (zuraca do lektury): Uffi Gotowe! Porządki w szafie zrobione. Teraz tylko czekaj na brak komplementów, obojętne spojrzenia i parę laczków na ryj od czasu do czasu. Teraz możesz już czekać, aż znowu przyjdzie II wojna światowa i wszystkie 
“Transfer” XV: 1-2 (2020), pp. 502-561. ISSN: 1886-554

pieczołowicie gromadzone przez lata kubeczki po kefirze nareszcie się przydadzą.

MAŁA METALOWA DZIEWCZYNKA: Puk puk!

HALINA: Kto tam?

MAŁA METALOWA DZIEWCZYNKA (zaglada $w$ garnki): To tylko znowu przyszła ja, II wojna światowa. Widzę, że nie dość, że ma pani dużo kubeczków, to jeszcze nagotowała pani pysznej broni biologicznej! Gratuluję.

HALINA: Co ty znów wygadujesz? Marsz do swojego braku pokoju.

MAŁA METALOWA DZIEWCZYNKA: Jak się zdaje tu właśnie jestem, ale jeszcze sprawdzę. Hop hop! Hop hop! Gdzie jestem? A tutaj. Ach tutaj, no to idź właśnie tutaj i tutaj zostań. Już się robi. 
“Transfer” XV: 1-2 (2020), pp. 502-561. ISSN: 1886-554

\section{SCENA 3}

Do mieszkania, nie używając pukania, z typowym dla osób nie posiadajacych do przekazania żadnej sensacyjnej informacji, a jedynie to sobie rojacej, podminowaniem, wchodzi Bożena. Jest monstrualnie gruba i porusza sie z widocznym trudem, nie mogac domknąc drzwi, wyrywa je i odkłada na bok. Sapią, stękając $i$ trzymając się boleśnie za kręgostup, pośpiesznie drepce w kierunku fotela, na którym niezwłocznie, jakby nie mogac utrzymać się na własnych nogach, siada. Poziom przedmiotów w mieszkaniu podnosi się o 40 centymetrów.

BOŻENA: Wybacz, że nie zadzwoniłam wcześniej do ciebie na komórkę, ale nie mam komórki, bo po co mi, skoro jestem gruba jak świnia. Więc po prostu wpadłam.

HALINA: Oczywiście ci tego nie mówię poprzez grzeczność, ale Boże, jakaś ty gruba, jak świnia. Cały dom mi zasapiesz.

BOŻENA: Dziękuję. Widzę to w twoim spojrzeniu, mimo wszystko mogłabyś jeszcze chwilę pogardliwie pofukać, żebym uniknęła jakichkolwiek wątpliwości, że jestem grubą świnią i nie powinnam się tak nachalnie szwędać innym ludziom po ich polu widzenia, mają prawo do wyboru powodów, dla których rzygają.

Korzystając z zaangażowania Haliny $w$ podpalanie palnika, Mała Metalowa Dziewczynka kręcaca się wszędzie w poszukiwaniu czegoś do zniszczenia albo oderwania, przechwytuje i niby nigdy nic zaczyna czytać magazyn.

MAŁA METALOWA DZIEWCZYNKA: Zodiakalna Gruba Świnia może się spodziewać w zeszłym kwietniu samych miłych 
“Transfer” XV: 1-2 (2020), pp. 502-561. ISSN: 1886-554

niespodzianek. W Biedronce pojawi się nowy rodzaj niedrogiej mielonki „Szynka drobiowa pradawna", skład: woda, skóry wieprzowe, płyn do mycia naczyń, płyn do spryskiwaczy, woda (97 procent), żelatyna, przyprawy; oraz nowy rodzaj przeterminowanej śmietany „Tylko O Parę Dni", skład: woda, żelatyna, barwnik biały, zagęszczacz, porzedzacz, odkamieniacz, odtruwacz, żywe kultury salmonelli. To, czego nie zjedzą inni, popij tym, czego nie wypiją. Nareszcie zaakceptuj siebie i całkowicie się zmień. W tym celu wychodź dużo z domu i spaceruj, bo jak przystało na zodiakalną Grubą Świnię, jesteś grubą świnią, ale nie wychodź i nie spaceruj, zwłaszcza innym ludziom po ich polu widzenia: mają prawo do tego, by rzygać $\mathrm{z}$ lepszych powodów.

Odkłada magazyn, jakby przez nikogo nie zauważona. Bożena z zainteresowaniem zerka na niego z trudnym do skrycia zainteresowaniem, ale nie mając odwagi go pomacać.

BOŻENA: O, jaka śliczna gazeta, „NIE DLA CIEBIE".

HALINA: A tak, „NIE DLA NAS".

BOŻENA: Bardzo ładna.

HALINA: Kupiłam sobie dzisiaj w kuble z makulaturą. Prawdziwa okazja - za darmo i w dodatku z rozwiązaną krzyżówką. Miła niespodzianka, gdzie ja bym miała głowę do jakichśtam krzyżówek!

BOŻENA: Ja od kiedy właściwie od zawsze obejmuję to stanowisko specjalisty usuwania zanieczyszczeń sanitarnych w przestrzeniach prywatnych własnych, kompletnie nie mam czasu na takie rzeczy. Praca niewymagająca, ale męcząca i niesatysfakcjonująca. 
“Transfer” XV: 1-2 (2020), pp. 502-561. ISSN: 1886-554

HALINA: Doskonale to rozumiem. Ja jako specjalistka przemieszczeń palet towarowych $\mathrm{w}$ przestrzeni sklepowej klasyczną metodą fizyczną, muszę wstawać wcześniej niż się położę i wracam z pracy dużo później niż znowu do niej wstałam. W braku przyszłości mają mnie jednak awansować na menedżerkę do spraw elektronicznego ustalania wagi realnej obiektów sektoru owoców i warzyw i myślę: a dlaczego właściwie nie spróbować?

BOŻENA: A pewnie, a kto jak nie ty? Języki - obce, doświadczenie jako dyspozytorka materiałów reklamowych w korpoltażu bezpośrednim ręcznym, ambasadorka zapachu „Stara Baba" w Polsce $\mathrm{w}$ promocji bezpośredniej $\mathrm{w}$ autobusach i tramwajach $\mathrm{z}$ dominującą nutą potu i delikatnie sekundującymi jej echami piżma, naftaliny i starej zupy...

HALINA (krzątając się przy kuchni i wykonując różne czynności, tyleż fachowe, co pozbawione sensu): A ja to już myślę: byle do tego urlopu, którego nie będę miała. Czytam, czytam i zdecydowałam się wreszcie. Nie ma mowy, w tym roku znowu nie pojedziemy na żadne wakacje.

BOŻENA: Coś ty!

HALINA: Ano tak! Znowu nie pojedziemy.

BOŻENA: A gdzie nie pojedziecie?

HALINA: Nigdzie.

BOŻENA: No a gdzie indziej? A my w tym roku nie pojedziemy nad morze. Boże, jak tam jest dla nas zbyt drogo! Nie mamy na to 
“Transfer” XV: 1-2 (2020), pp. 502-561. ISSN: 1886-554

pieniędzy! Poza tym jestem gruba jak świnia i nie powinnam się tak nachalnie szwędać innym ludziom po ich polu widzenia.

HALINA : A pewnie a jak.

BOŻENA: Po drodze nie zahaczymy jeszcze o Kobyłkę, gdzie mieszka kuzynka... I wprost stamtąd też nie pojedziemy nigdzie!

HALINA: No to pewnie się spotkamy - masz numer na mój brak komórki. Nigdzie, stare dobre nigdzie, wszystkie wspomnienia mam właśnie stamtąd. Chociaż od paru lat bardzo tam tłoczno, po prostu wszyscy się tam pchają, sama mam tam szwagra, szwagierkę, brata, bratową, wuja, kuzynkę, siostrę...

BOŻENA: A jak ciemniutko tutaj! A jak ciaśniutko!

HALINA \{energicznie przestawiajac wózek Staruszki, który zasłania jej $i$ uniemożliwia jednoczesne rozmawianie, śledzenie programu telewizyjnego i macanie gazety): Ojciec szklorz, matka szyba. Jak mama myśli, że jest już przezroczysta, to wciąż jeszcze mama nie jest. A ty marsz do swojego braku pokoju!

MAŁA METALOWA DZIEWCZYNKA: Jak się zdaje, właśnie tam jestem, ale jeszcze sprawdzę. Hop hop! Hop hop! Gdzie jestem? A tutaj. No, właśnie, to tak jak myślałam.

Mała Metalowa Dziewczynka znowu, przez nikogo niezauważona, przechzuytuje pismo.

MAŁA METALOWA DZIEWCZYNKA: Odwrotnie niż w nowocześnie zaprojektowanych mieszkaniach, w których członkowie rodzin bezskutecznie nawołują się godzinami po przestron- 
“Transfer” XV: 1-2 (2020), pp. 502-561. ISSN: 1886-554

nych korytarzach, hallach i osobnych pokojach, usiłując dociec, gdzie sami oni się znajdują, nie mówiąc już o ich bliskich, to klaustrofobicznie ciasne pomieszczenie sprawia wrażenie niedużego, a to właśnie w nim wielopokoleniowa familia wspólnie śpi, je, wydala, żyje, nie śpi, przewraca się z boku na bok, wymiotuje i dostaje sraczki, nie żyje i umiera, nie musząc się przy tym w nim w ogóle szukać, a wręcz przeciwnie: ciągle i ciągle się w nim znajdując. Efekt ten osiągnięto przez prosty trick architektoniczny, mieszkanie zmyślnie podzielono tak, aby brak pokoju Małej Metalowej dziewczynki, brak świętego spokoju osowiałej inwalidki i niepokój Haliny (51 1.) mieścił się dokładnie w tym samym jednym pokoju, gdzie jak dzień długi przekazują sobie brak pokoju. Aż trudno uwierzyć, że oprócz nich udało się tu zmieścić cały oryginalny komplet mebli $\mathrm{z}$ lat siedemdziesiątych (płyta pilśniowa). Ich powierzchnie udało się przez lata zmatowić, porysować i szczelnie pokryć dziecięcymi maziajami, a misz-masz produktów spożywczych, napoi wyskokowych i wydzielin fizjologicznych tworzy na komplecie „Mieszko" stylizowany na zwykły brud niezwykły pa-limpsest. Tapety na brzegach lekko zmoczono i naddarto, grzyba na ścianie, który przykryty został kilimem, w ogóle nie ma. Pudełko po chałwie, ładnie oprawione wieczko bombonierki „Solidarność", plastikowa wstążka wpięta w doniczkę z firodendronem, pałętające się tu i ówdzie obierki jarzyn, kostki od kurczaka, rozkoszne, puszyste koty kurzu, rocznik bezpłatnej gazety metro, rzucona „niby to mimochodem" tubka dentoseptu, kubeczki po kefirze, to wcale nie żadne łobuzy przewróciły śmietnik tylko...

HALINA (zirytowana, wyryioajac jej gazetę i z powrotem kładac w bezpiecznym miejscu na stole): Nie daje chwili spokoju! 
“Transfer” XV: 1-2 (2020), pp. 502-561. ISSN: 1886-554

MAŁA METALOWA DZIEWCZYNKA: Jestem w swoim braku pokoju! 
“Transfer” XV: 1-2 (2020), pp. 502-561. ISSN: 1886-554

\section{SCENA 4}

Halina przy kuchni, grzebie w swoich garnkach. Metalowa Dziewczynka rozpędza wózek ze Staruszka, po czym wskakując zwinnie na jego tyl jeździ dookoła telewizora, wreszcie wózek przewraca tu jak kulki z flippera moga wysypać się wszystkie ukryte $w$ pledziku pigułki, a nie potrafiac na powrót umieścić babci $w$ pozycji pionowej, porzuca ja na dywanie. Jeszcze chwile krąży w poszukiwaniu jakiegoś utraconego zajęcia, po czym zaczyna rysować prętem po politurze mebli. Przewrócona Staruszka w pozycji poziomej plecie warkocze albo robi na drutach 10 metrowy rękaw od swetra. Potem odklada robótkę $i$ szamoczac się, rozpaczliwie usituje się podnieść. Bożena na swoim fotelu coraz śmielej przybliża się do „Nie dla Ciebie", wreszcie sięga drżaca dłonia $i$ początkowo nieśmiało przeiuraca kilka stron, wreszcie zaczyna ja przegladać z narastająca śmiałościa, a nawet czyni uwagi.

BOŻENA: A psychozabawę masz tu jeszcze niewypełnioną.

HALINA: Ano widzisz.

BOŻENA: Wypełnię, bo będzie na zmarnowanie. Czy jesteś spontaniczną wycieczkowiczką, ciepłolubną domatorką, seksowną wampirzycą, zapracowaną pracoholiczką, fantazyjną wichrzycielką, niepoprawną globtroterką, grubą świnią czy przecenioną mrożoną pangą z Kerfura....

HALINA (wycierajac ręce $w$ sweter i zagladajac jej przez ramię): Ja niepoprawną globtroterką. 
“Transfer” XV: 1-2 (2020), pp. 502-561. ISSN: 1886-554

BOŻENA: A pewnie: ja tak samo. Niepoprawna globtroterką wszystkie odpowiedzi A. Ale zaznaczę dla niepoznaki jeszcze jedno B. Gotowe!

HALINA: Moje zakreśl na inny kolor, żeby nie pomylić. Niby głupia zabawa, a jak się zgadza.

BOŻENA: Zgadza się jak nic! Pamiętasz, jak nie byłam we Francji i moja noga nigdy już tam nie postanie? Fasolka po bretońsku i bułka paryska, oni się tym wprost zajadają, a to taka buła jak wrocławska albo nawet gorsza. Monumentalny zarys tej znanej wieży Eiffli, która że taka niby wysoka, taka niby wysoka, a na zdjęciu w gazecie o może taka, mniejsza od mojego palca.

HALINA: To jeszcze nic, myśmy nie byli we Włoszech. Ale nie byłam zadowolona W OGÓLE, że tam nie pojechaliśmy. Zapomnij! Do jedzenia nic specjalnego. Włoszczyzna, orzechy, kapusta włoska, pieczeń rzymska, ta ich pizza to mrożona $\mathrm{z}$ promocji z Tesco, wyobraź sobie, że z pleśnią. Zjadłam, bo nie wyrzucę, ale żeby strawić to bardzo przelekramowane, więc pojechaliśmy jeszcze do Rygi. Poza tym nie było sensu jechać, bo papież już nie został człowiekiem, tylko Niemcem. Dobrze, że tam nie byłam i nie zrobiłam zdjęć, to ci nie pokażę.

OSOWIAŁA STARUSZKA (podbija na swoim skrzypiacym wózku): Aż do Warszawy wkroczyli Niemcy...

MAŁA METALOWA DZIEWCZYNKA: Niemcy wiem, to ci co tak jodłują! 
“Transfer” XV: 1-2 (2020), pp. 502-561. ISSN: 1886-554

HALINA (pouczajaco): Niemcy to ci, co mieszkają w RFN-ie i nie myją siatek, tylko wyrzucają, a kubków po kefirze to już w ogóle, no ciekawe. Jak im skóry po kurczaku zostaną, to ciekawe, w czym 
“Transfer” XV: 1-2 (2020), pp. 502-561. ISSN: 1886-554

galaretkę sobie zrobią. Potem jak przyjdzie znowu II wojna światowa, to do nas będą przychodzić.

Bożena z niewiadomokad wyciaga osmalony $i$ ośliniony album ze zdjęciami.

HALINA: Jaka gruba! Jaka nieopalona!! Ho ho ho. Że się w kadrze zmieściłaś, no no.

BOŻENA: Tu nie byliśmy. I tu też nie byliśmy. A to właśnie nie my. Gdybym miała ten album, to bym ci pokazała.

Równie nagle chowa album.

HALINA: Takim to dobrze. Nie żyć. Umierać.

BOŻENA: No a co? Każdy chce jakoś nie żyć. 
“Transfer” XV: 1-2 (2020), pp. 502-561. ISSN: 1886-554

\section{SCENA 5}

Dalsza stagnacja. Halina i Bożena pogrążone w swoich myślach z rękami założonymi refleksyjnie na brzuchach. Skrzypienie wózka staruszki, skrzypienie gwoździa Malej Metalowej Dziewczynki na politurze mebli lub zgrzyt i iskrzenie przecinanych przez nia kabli.

HALINA: A może byś coś zjadła? Przeczytałam tu świetny przepis: leczo. Tą mielonkę pradawną z Tesco nie wyrzucasz, tylko obierasz z pleśni, jeśli jest już śliska, to podsmażasz, po czym tniesz na kilka plastrów szynki parmeńskiej. Kanapkowy seropodobny trzesz na parmezan, $w$ konsystencji powinien przypominać już wymiędloną plastelinę, inaczej wciąż jeszcze się do czegoś może przydać. Wrzucasz to do starej grzybowej. Powinna już lekko opalizować.

BOŻENA: A skąd wziąć grzybową?

HALINA: Ugotować tydzień temu.

BOŻENA: Rzeczywiście bardzo proste. A te gorzkie zjełczałe na wierzchu to co?

HALINA: To orzeszki piniowe.

BOŻENA: Piniowe? A jakie to: piniowe?

HALINA: Też pierwsze słyszę. Ale całkiem smaczne, bardzo podobne do tych ziemnych $z$ promocji, a wręcz to właśnie te same. Mam na nie sposób, jak ich nie jeść, to w ogóle nie czuć zjełczałym. Można jeszcze dodać cenę z chleba, żyły z mięsa, kości... Nie wyrzucać, usmażyć na łoju, ugotować na kurzych łapach, zmielić, usmażyć znowu, nie wyrzucać, tylko mocniej osolić i w kubeczki 
“Transfer” XV: 1-2 (2020), pp. 502-561. ISSN: 1886-554

po kefirze, odgrzać, podgrzać, odsmażyć, zjeść, a jak już by się pieniło, to zwymiotować, a czasem nawet i wcale nie, i gotowe. Teraz się ze mnie śmieją, a jak przyjdzie następnym razem II wojna światowa, to jeszcze będą pałaszować, aż im się uszy będą trzęsły.

BOŻENA: Dziękuję, taka gruba, a jeszcze dokłada do pieca. Wcina, aż jej się uszy trzęsą. Żryj, żryj świnio, żryj, bo to z makiem. Ja bym to podawała jeszcze $z$ dupką od chleba.

HALINA: Przepraszam, że tak to wszystko na niby, ale wszystko zjadłam, zanim się zmarnowało.

BOŻENA: No właśnie. No to nic. Będę lecieć, jutro muszę wstać wcześniej, niż się położę.

HALINA: Ja też jak wrócę znacznie później niż znowu wstałam, to jeszcze muszę wytrzeć jezioro gazetą.

BOŻENA: Już mnie tu nie ma.

HALINA: Jakby co, to mnie też nie ma.

Tymczasem Mała Metalowa Dziewczynka znów chytkiem podkrada i zaczyna czytać damskie czasopismo.

MAŁA METALOWA DZIEWCZYNKA: Efekt pozornego chaosu i bric-a-bracowej przypadkowości w tym pięknym, starym, doszczętnie zdewastowanym mieszkaniu został uzyskany przez prawdziwy choas i przypadkowość. Panujący wszędzie śmietnik do złudzenia przypomina śmietnik z prawdziwego zdarzenia, będąc $\operatorname{nim} \mathrm{W}$ istocie. Opinia naszego eksperta, stylisty wnętrz: ten rozpaczliwy syf to naprawdę piękne stare przedwojenne mieszkanie. Ale mimo że w pomieszczeniu mniej więcej od wojny 
“Transfer” XV: 1-2 (2020), pp. 502-561. ISSN: 1886-554

przeprowadzany jest konsekwentnie brak remontu, ciągle brakuje w nim modnej od kilku sezonów czystości, suchości i przestrzeni. Możliwe są dwa rozwiązania tego nieprzyjemnego koszmaru. Pierwszym, dość kosztownym, jest przerobienie tej komórki na piwniczkę na wino (ale już nie, na przykład, trzymanie tu sprzętu narciarskiego czy snowboardowego - wilgoć!), a samemu wyprowadzenie się do luksusowego apartamentu. Zgrabne półki i stojaki, i ich rozmyślne rozmieszczenie mogą umożliwić kilku naprawdę przesmacznym buteleczkom bycie tu trzymanymi! Drugie, ekonomiczne: członkowie rodziny zabijają się nawzajem i powracają $\mathrm{w}$ bardziej korzystnych inkarnacjach, albo tez po prostu nigdy się nie rodzą i nie żyją i tak jest lepiej dla nich wszystkich, a zwłaszcza dla wszystkich innych wszystkich. Kamienica najlepiej, żeby została zburzona (dobrze by było, gdyby jeszcze podczas wojny - później może być $\mathrm{z}$ tym problem), a na gruzowisku wybudowany został względnie elegancki budynek wielopiętrowy, normalni ludzie kupili w nim mieszkanie, wstawili tu tapczan z Ikei RIKKA, stolik z Ikei STAKKA, wazon ROSTE, kwiaty HAMMA, wodę do kwiatów LIKKE, powietrze pokojowe GRETTA, siebie samego SIEBBIE i spłacając kredyt przez następne czterdzieści lat, wpadali tu z pracy się zdrzemnąć, umyć dupsko i z powrotem. 
“Transfer” XV: 1-2 (2020), pp. 502-561. ISSN: 1886-554

\section{Entre nosaltres tot va bé}

\section{Dorota Masłowska}

Traducció de Pau Freixa

Per a la meva mare, per celebrar 25 anys juntes en aquest món (i per a l'Agata, és clar) 
“Transfer” XV: 1-2 (2020), pp. 502-561. ISSN: 1886-554

\section{PERSONATGES:}

PETITA NOIETA METÀL·LICA

HALINA

BOŻENA

TRISTA VELLETA EN CADIRA DE RODES

HOME

ACTOR

PRESENTADORA

EDYTA

MONIKA 
“Transfer” XV: 1-2 (2020), pp. 502-561. ISSN: 1886-554

Acte 1

\section{ESCENA 1}

Vell edifici d'habitacles humans a Varsòvia. Apartament d'una sola estança. Dues portes, una dóna a un pati amb contenidors per als residus secundaris, de darrera l'altra arriba un soroll constant de vàter, barboteig aquàtic, degoteig de canonades. Una finestra darrera la qual va passant en una proximitat immediata i de forma constant el salvatge i omnívor carrusel de la gran ciutat amb els seus tramvies, cotxes, clàxons i avions volant arran de terra, que fan tremolar sobre una petita barra una ampolla amb restes d'aperitiu barat, unes misterioses piràmides d'olles i plats amassats $i$ enganxats amb restes de menjar als fogons, se sacseja la imatge al televisor, eternament encès, i xiula una bombeta a l'aranya. Tota l'estona l'interior dóna la impressió d'estar construït sobre un terra que s'esberla o excavat amb excavadora. La Petita Noieta Metàl-lica, vestida de mariner i amb un gran llaç oscillant lliurement entre els seus rals cabells metàl-lics, i la seva àvia, la Trista Velleta en cadira de rodes arrastrant embullades trenes de cables o teranyines per la catifa, s'estan en aquest interior com passatgeres d'un vaixell que s'enfonsa: sostingudes entre el pànic i l'avorriment, entre una activitat irreflexiva i una estagnació igualment irreflexiva, entre la claustrofòbia i l'agorafòbia, amb la incertesa tan característica de les persones condemnades a compartir companyia de si es persegueixen o més aviat fugen l'una de l'altra o si, cansades d'una cosa i de l'altra, romanen immòbils. Entre els seus alterns atacs d'estupor i sobreexcitació, la mare de la Noieta, la Halina, realitza amb la impassibilitat d'un animal de tir automàtic les tasques automàtiques de la casa i en aquest precís instant surt a llençar les deixalles.

TRISTA VELLETA EN CADIRA DE RODES: Aiii, recordo el dia que va esclatar la guerra. 
“Transfer” XV: 1-2 (2020), pp. 502-561. ISSN: 1886-554

\section{PETITA NOIETA METÀL·LICA: Què va esclatar ?}

TRISTA VELLETA EN CADIRA DE RODES: La guerra. Aleshores jo era una noieta preciosa i tenia una cara jove com la primavera, el cor em colpejava al pit com un petit rossinyol atrapat en...

PETITA NOIETA METÀL·LICA: En un pot.

TRISTA VELLETA EN CADIRA DE RODES: Aleshores encara caminava, Déu meu, com caminava.

PETITA NOIETA METÀL-LICA: Vinga va, com exageres, iaia: caminava i caminava.

TRISTA VELLETA EN CADIRA DE RODES: Sí que caminava, me'n recordo que...

PETITA NOIETA METÀL LICA: Potser et vas afartar de caminar de tant caminar, iaia. Ara per fi pots no anar enlloc. T'ho ben juro que, si jo fos tu, no hi aniria, ja ho crec que no. A l'escola, a anglès i encara trobaria un parell de llocs més on no anar.

TRISTA VELLETA: Amunt i avall, amunt i avall. Abans de la guerra es caminava que donava gust. Al cinema, a menjar neules, llaminadures, cap al riu. Per la sorra, per terra, cap al riu. Per l'herba, per les violetes envellutades, cap al riu, els dies de calor, quan la gran llosa de la seva superfície cristal-lina, esquinçada pels rajos de sol com a través de una garrafa...

PETITA NOIETA METÀL·LICA: Però a quin riu?!

VELLETA: Com que a quin riu? Al Vístula.

PETITA NOIETA METÀL·LICA: A aquest femer? Jesús, Maria i Josep... 
“Transfer” XV: 1-2 (2020), pp. 502-561. ISSN: 1886-554

VELLETA: Quin femer? Aquí, al Vístula. Uns esclops als peus, un tros de pa a la mà i au! Ens banyàvem, preníem el sol, somiàvem el més preciós dels somnis, el més sagrat somni de la joventut, net com les llàgrimes que per les galtes...

PETITA NOIETA METÀL·LICA: I què vols dir "pa”? No, no, feia broma... A mi també m'encanta banyar-me al Vístula, es un plaer intemporal. Sempre quan surto a la riba, sacsejant-me amb força la gasolina, agafo el xarampió, la febre tifoïdal i intoxicació de cadmi, i em moro, i així em donen permís per a no haver d'anar a l'escola.

VELLETA: Pescàvem gardins, diminuts, salvatges, es movien d'una manera... belluguets, amb les escames llustroses i platejades fregant-nos les palmes de les mans.

PETITA NOIETA METÀL-LICA: Iaia, però què dius ara? A vegades nosaltres també pesquem presers. Així és com els hi diem als condons podrits. I com s'escorren, s'escapen de les mans! Els nois se'n riuen, però a mi se'm trenca el cor quan penso quants potencials polaquets, espavilats i oportunistes, s'escaquegen cada dia de l'existència.

TRISTA VELLETA: Tothom deia que Hitler, el meu pare deia que un tal Hitler...

PETITA NOIETA METÀL-LICA: I com s'escorren! Potser es pensen que a mitja Polònia el Vístula gira i se'n va directe cap a Amèrica i que allà naixeran amb un bitllet de cent cinquanta dòlars a una mà i un de tres-cents quinze a l'altra i que nosaltres ens esbatussarem aquí tot sols en aquest camp de patates. Naixeran, naixeran, amb una escombra i una cullera i un osset rosegat del gall dindi de Nadal, del contenidor de les escombraries! O millor dit: no naixeran, perquè nosaltres els... plaf i ja està. 
“Transfer” XV: 1-2 (2020), pp. 502-561. ISSN: 1886-554

TRISTA VELLETA: Però qui havia de creure que un tal Hitler, nosaltres érem joves, el cor es bellugava al pit... es bellugava el cor com...

PETITA NOIETA METÀL·LICA: ...un condó atrapat en un pot!

La Halina entra a l'apartament, espolsant-se les sabatilles a consciència. Porta una galleda tristament rònega, buida de les deixalles que contenia. Contenta, es neteja a consciència les sabatilles d'estar per casa a la catifa i penja la clau en un ganxo. També pot portar carbó del soterrani, cogombres en conserva o alguna cosa tan adequada a l' hivern per portar la roba de llit a la bugaderia com un trineu infantil, però el més important és que porta sota el braç un tresor que acaba de trobar: una revista femenina, que ja ha estat intensament llegida per algú, rescatada del container de reciclatge de paper.

HALINA: Quin pot? No diguis paraulotes!

PETITA NOIETA METÀL·LICA: Ui, la mama, tan indignada ella com si m'hagués concebut pel mètode d'assentar-se en una bruta butaca d'un PKP Intercity.

La Halina dona voltes pel seu regne: els fogons plens fins el sostre d'un festival de diferents olles i paelles, socarrimades i rovellades, gastades receptes de calendari, fulles publicitàries del Dia, fulls anunciant escoles d'idiomes esmerçadament guardades, etiquetes de conserves, vasos de iogurt ben rentats. La Petita Noieta Metàl-lica li va al darrera, observant golosament per sobre l'espatlla, salivant i intentant agafar la caixa de les llaminadures. La Halina li pica les brutes potetes.

HALINA: T'has menjat el dinar?

PETITA NOIETA METÀL·LICA: I què hi ha per dinar? 
“Transfer” XV: 1-2 (2020), pp. 502-561. ISSN: 1886-554

HALINA: Doncs un pet sec amb vinagre.

PETITA NOIETA METÀL·LICA (aixecant la tapa d'una olla): Un pet sec, el meu menjar preferit. I què és el que fa una pudor tan espantosa?

HALINA (agafant-li l'olla i tancant categòricament la nevera): Deixa, això m'ho escalfaré jo per sopar.

TRISTA VELLETA: Els alemanys van arribar fins a Varsòvia. I jo només amb el vestit, només amb la meva bossa, i a la bossa només...

PETITA NOIETA METÀL·LICA: Alemanys, alemanys, em sona la tal Alemanya... calla, ja ho sé, són aquells que tota l'estona fan yolorohihuuu!

TRISTA VELLETA: Jo amb la bossa i prou, amb aquell vestit estampat de rosetes...

PETITA NOIETA METÀL·LICA: ....segur que podrides... vull dir dessecades!

TRISTA VELLETA: ...tornava del Vístula, perquè feia un dia molt calorós, amb els ulls plens d'atzur de tant contemplar la somnolenta, fresca, sabonosa, límpida...

PETITA NOIETA METÀL·LICA: ....bruta, tèbia, verdosa, espumosa, vítria superfície d'aquest abocador...

TRISTA VELLETA: ...quan de cop i volta...

PETITA NOIETA METÀL·LICA: Quan de cop i volta pum!

TRISTA VELLETA: Què passa? 
“Transfer” XV: 1-2 (2020), pp. 502-561. ISSN: 1886-554

PETITA NOIETA METÀL·LICA: Un burro per la plaça. Fum, flames, foc... Tu ho vas veure, no, iaia?

TRISTA VELLETA: Si vaig veure què?

PETITA NOIETA METÀL·LICA: Com es cremava?!

TRISTA VELLETA: Què es crema?

PETITA NOIETA METÀL·LICA: Una BICICLETA. Una bicicleta.

TRISTA VELLETA: Quina bicicleta?

PETITA NOIETA METÀL LICA: No ho sé. Se sentia un tuf terrible de bicicletes cremant-se, a mi m'és igual, però aquella pudor característica no la confonc amb res.

TRISTA VELLETA: No, no ho vaig veure.

PETITA NOIETA METÀL·LICA: I jo sí!?

Impassible als malentesos familiars la Halina, havent sacsejat amb força les tapes d'olles i paelles, neteja unes engrunes invisibles de sobre la taula amb la mà, es frega les mans en el jersei i sospirant en direcció al cel es posa a llegir la revista recent adquirida.

PETITA NOIETA METÀL·LICA: Què tens aquí, mama, una nova revista cara?

HALINA: És una revista il-lustrada. NO ÉS PER TU. Estava al container de reciclatge. Gratis, així que dic: doncs res, me la compro, què passa? m'ho puc permetre.

PETITA NOIETA METÀL·LICA: No està malament.

HALINA: Es d'abril de l'any passat. De totes maneres no és per mi. 
“Transfer” XV: 1-2 (2020), pp. 502-561. ISSN: 1886-554

PETITA NOIETA METÀL-LICA: Mira, mama, els mots encreuats vénen amb la solució.

HALINA: Així no els hauré de solucionar, ja tinc la paraula clau: tête-à-tête primaveral.

PETITA NOIETA METÀL-LICA: A veure, mama. Tête-à-tête primaveral... un moment... magrejada de primavera al costat del femer?

HALINA: No ha menjat ja l'àvia?

PETITA NOIETA METÀL·LICA: Iaia, no has dinat ja?

TRISTA VELLETA: I què hi havia?

HALINA: Samfaina.

PETITA NOIETA METÀL-LICA: Samfaina: Flopis amb pebrot i esperma d'alienígenes catalans. Vegi també: sopa de la setmana, sopa del mes, aprofitament, Segona Guerra Mundial, fam.

TRISTA VELLETA: Ah, no no no, llavors no he menjat.

PETITA NOIETA METÀL·LICA: La iaia no ha menjat.

HALINA: I això perquè?

PETITA NOIETA METÀL·LICA: I jo què sé. Segur que fa règim. Jo també faig règim.

HALINA: I... Avui no ha sortit ja la iaia? 
“Transfer” XV: 1-2 (2020), pp. 502-561. ISSN: 1886-554

PETITA NOIETA METÀL·LICA: Jo, jo, sempre jo! Jo no he portat la iaia enlloc.

HALINA: Molt bé, així ja no hauré de portar-la enlloc, cosa que tampoc faria, ja que avui torno de la feina després de les 23.

PETITA NOIETA METÀL·LICA: Al cap i a la fi la iaia es passa tot el dia en una casa sense ascensor, no té a ningú amb qui poder xerrar i jo quan torno de l'escola i em passo la santa tarda assentada davant de la tele, no tinc temps de, a més a més, treure aquest vell nap a passejar! Alegres onejaven al vent les meves trenetes quan no anàvem per un parc en plena tardor i ella m'explicava aquelles delicioses històries seves de quan va anar a aquell camp de concentració. Em fa l'efecte que alguna cosa aprofita d'Allo, allo i de Quatre blindats i un gos, però ella mateixa. Al cap i a la fi és postmodern.

HALINA: Què xerres ara? No diguis paraulotes!

PETITA NOIETA METÀL·LICA: Jo tampoc ho sé, m'ho acabo de baixar d'Internet.

Així doncs, no passejàvem així de bones amunt i avall per les avingudes daurades per la tardor, quan sense sortir d'enlloc se'ns enganxa un intrús. Em sembla que era alemany, perquè era cultural i fins i tot ens va fer una reverència, va fer picar els talons i va i diu: Bon dia, em dic Arzheimer, però el seu cognom em va marxar del cap... com va dir que es deia... no me'n recordo, fins aquest punt se me'n va l'olla? Un cognom molt conegut que comença per A... com era... bé, no importa. En qualsevol cas, acabava d'oblidar el cognom d'aquest i ja en surt un altre, també saluda amb els talons, molt cultural ell, amb una perruca així al cap i diu: sóc aquell famós filòsof neerlandès, aquell que, com ho va dir? aquell que es va oposar al dualisme cartesià... mmm... ESCLEROSA. Sí, exacte.

Quan no han començat a fer merder, que ja semblava un galliner, he entès que la meva presència a l'habitació que l'àvia no té era 
“Transfer” XV: 1-2 (2020), pp. 502-561. ISSN: 1886-554

dispensable i fins enutjosa, així que per no molestar-los he vingut a la meva habitació, que tampoc tinc, i tota la tarda que m'estic aquí amb vosaltres assentada davant de la tele.

La Halina adopta la típica postura de persona llegint còmodament una revista i alhora mirant la televisió, la visió de la qual dificulta la Velleta amb el seu anar i venir per tot arreu amb la seva cadira de rodes.

HALINA: Eh, el pare de vidre, la mare de cristall. La mama segueix pensant-se que és invisible. Menja't els flopis amb pebrot, mama. Per a qui no els he preparat sinó? Tota la setmana que els estic passant d'olla en olla...

PETITA NOIETA METÀL·LICA: Segur que fa règim, ja no vol estar tan escarransida, sinó ser transparent.

TRISTA VELLETA: Ja ho crec que caminava! Abans de la guerra sí que es caminava. No sabeu com, i també corríem. Al cinema, a menjar neules, llaminadures, cap al riu.

PETITA NOIETA METÀL-LICA: Iaia, si segueixes menjant tantes neules, tocinillos i altres porqueries, doncs felicitats. Mai t'aprimaràs, iaia.

TRISTA VELLETA: Per la sorra, pel terra, cap al riu. Només amb un tros de pa a la mà i au...

PETITA NOIETA METÀL·LICA: Millor que t'oblidis del pa, iaia, sobretot del blanc: engreixa. I és important moure's. Com segueixis assentada tot el dia en aquesta cadira de rodes, iaia, no t'aprimaràs mai, t'has de bellugar més, sobretot t'hauries d'empènyer tu mateixa. Silenci, algú truca a la porta. Toc, toc.

TRISTA VELLETA: Qui hi ha? 
“Transfer” XV: 1-2 (2020), pp. 502-561. ISSN: 1886-554

PETITA NOIETA METÀL-LICA: Ja obro jo, vaig a veure qui... Ah no... Em pensava que havia arribat la Segona Guerra Mundial.

HALINA: Què t'empatolles?

PETITA NOIETA METÀL·LICA: T'ho juro. Res, devien ser avions teledirigits. 
“Transfer” XV: 1-2 (2020), pp. 502-561. ISSN: 1886-554

\section{ESCENA 2}

El pis i tot com abans. La Velleta en un estat d'estupor, la Noieta s'entreté avorrida amb un petit gall clavat a un pal. No obstant, en un moment donat, considerant aquesta ocupació poc creativa, comença a empènyer l'àvia pel pis amb el seu pal. La Halina, una mica irritada amb el seu anar i venir, però també una mica impregnada, s'enfonsa en la lectura de la seva revista, mentre va agafant amb una espècie d'exercicis de circ objectes que cauen dels armaris i les lleixes. Pel patí poden passar algunes persones que van a llençar les deixalles als contenidors corresponents. Entre els contenidors pot aguaitar la Bożena, monstruosament grassa, com un comando amagant-se de la mirada de les persones darrera els contenidors, que no poden amagar el seu cos insultant de tan gros. La Trista Velleta aconsegueix deslliurar-se del joc embafador $i$ ràpidament es tanca amb clau al lavabo envoltada pel sedant regalimar de l'aigua.

HALINA: Ja floreixen les prímules i la primavera arriba a tot vapor, temptant-nos amb la seva formosa aura.

Ara ve més de gust anar a oxigenar-se tot passejant, la bicicleta torna a fer gràcia. Ara ve més de gust no anar a oxigenar-se tot passejant, la bicicleta, que no posseeixes, torna a no fer gràcia. Les tardes assolellades inviten a l'activitat física i a trobar-se amb els amics, amb qui no et trobes, perquè no els tens i a sortir de la ciutat i del restaurant, if you know what I mean. És hora d'endreçar el guarda-roba de primavera. Pel penjador no es passegen grisalles, marrons, mitges gruixudes, pesats jerseis, abrics i caçadores.

També ve de gust no posar-se aquests vestits lleugers, que no tens, i les mitges primes, que tampoc tens. Segurament tampoc tens jaquetes més lleugeres, però per a la que tens, segur que estàs massa grassa. No passa res. Heus aquí les nostre propostes de l'any passat que no et permetran aterrar bruscament al marge de tot amb la sensació d'haver-te perdut les tendències de primavera. 
“Transfer” XV: 1-2 (2020), pp. 502-561. ISSN: 1886-554

PETITA NOIETA METÀL-LICA: Només cal espolsar una mica les arnes, una mica de xiu-xiu desodorant, rentar un mica, no rentar una mica, no rentar gens ni mica, no treure de l'armari i portar el mateix amb el que s'ha dormit i dormir amb el mateix que s'ha portat, espolsar una mica, no tenir absolutament res i llestos! Cap esforç i en canvi un efecte proporcionalment no més gran.

HALINA: Faldilla: Tesco, 28 zlotys. La taca de greix li afegeix misteri. Samarreta: de l'armari, gastada a l'altura de les tetes. Grisalles, marrons i groc d'orina, taques greixoses i trossos gastats són els hits d'aquesta temporada, com els de qualsevol altra temporada. Taques de suor. El nostre truc: més aviat que tard apareixen soles. Mitjons d'home: Mercat dels Encants de l'Estadi de la Dècada, 17 parells 10 zlotys. Sabates: cuir artificial. "Tot a cinc zlotys", 12 zlotys. Bossa: bossa de plàstic, 1,50, Lidl. Pràctica i gran, capacitat: 10 quilos de patates, 5 ampolles de vinagre, potes de pollastre, el número d'ahir del diari gratuït "Metro" i a més hi cap un moneder petit. Es pot rentar al safareig.

PETITA NOIETA METÀL·LICA: Tractament de la primavera passada per a tenir un cutis emblanquit per l'hivern, destrossat pels cigarrets, per una alimentació impròpia i per malalties coronàries.

HALINA: Renta't la cara amb sabó i unta't amb crema Nivea o amb margarina normal. També es recomana fregar-se la cara amb una tovallola.

PETITA NOIETA METÀL-LICA: El nostre consell: La vostra crema Nivea, perquè us duri més temps, no la feu servir.

HALINA: La meitat dels cabells, no us els renteu amb el vostre xampú habitual i l'altra meitat tampoc. El nostre truc: quant més sovint no ho fas, millor es veu que no en tens i més aguanta aquell inquietant olor d'armari per a les sabates i de cansalada rància. 
“Transfer” XV: 1-2 (2020), pp. 502-561. ISSN: 1886-554

L'abril de l'any passat tindràs finalment ocasió de que el sol de primavera no faci lluir les teves tristes i greixoses metxes.

Havent esperat una bona estona, la Velleta empenyent-se amb dificultat torna cap a dins del pis.

PETITA NOIETA METÀL·LICA: La cadira de rodes no és d'oli: aquests xerrics penetrants permeten deduir a la perfecció que acaba d'entrar i que no pararà de fer xivarri...

HALINA: Mira, la mama, m'hauria jugat el cap que seia allà, perquè allà ningú l'emprenya... i no m'equivocava, no... (amb un gest enèrgic, encara llegint, desplaça la cadira de rodes de la Velleta de tal forma que no li tapi el televisor).

PETITA NOIETA METÀL.LICA (a la Velleta, fent veure que també llegeix) L'abril de l'any passat tot serà com era. Rebràs una carta secreta, pot ser una reclamació de la companyia del gas! Dies significatius: el quinze. Se t'escamparan per terra les boletes de naftalina. Dies insignificants: la resta. El teu color de la sort: transparent. El teu mineral preferit: una pedra al ronyó.

HALINA (torna a la lectura): Uff! Ja està! Ja hem endreçat l'armari. Ara només cal esperar que no et tirin cap floreta, les mirades indiferents i un parell d'espardenyes per barba de tant en tant. Ara ja pots esperar que torni a venir la Segona Guerra Mundial i que tots els pots de iogurt acumulats curosament durant tants anys finalment et serveixin per alguna cosa.

PETITA NOIETA METÀL·LICA: Toc, toc.

HALINA: Qui hi ha?

PETITA NOIETA METÀL-LICA (es mira les olles): Sóc jo que he tornat, la Segona Guerra Mundial. Veig que no en té prou amb 
“Transfer” XV: 1-2 (2020), pp. 502-561. ISSN: 1886-554

tenir molts de pots, que a més ha preparat una deliciosa arma biològica. La felicito!

HALINA: Un altre cop, què dius ara? Marxant cap a l'habitació que no tens.

PETITA NOIETA METÀL-LICA: Jo diria que sóc exactament aquí, però ho tornaré a comprovar. Hop hop! Hop hop! On sóc? Doncs aquí. Ah... aquí, doncs vine aquí i queda't aquí. Ara mateix! 
“Transfer” XV: 1-2 (2020), pp. 502-561. ISSN: 1886-554

\section{ESCENA 3}

La Bożena entra al pis, sense trucar, amb la irritació típica de les persones que no tenen cap informació interessant a comunicar, a part de la que s'imaginen. És monstruosament grassa i es mou amb visible dificultat. No podent tancar bé la porta, l'arrenca i la deixa a un costat. Panteixant, gemegant, agafant-se dolorosament la columna vertebral, s'afanya maldestra cap a la butaca i s'asseu immediatament, com si no es pogués tenir sobre les cames. El nivell d'objectes al pis s'eleva 40 centímetres.

BOŻENA: Perdona que no t'hagi trucat abans al mòbil, però és que no tinc mòbil, perquè què en faria si estic com una truja. Així és que he vingut i ja està.

HALINA: Evidentment jo no t'ho dic per cortesia, però Déu meu, que grassa que estàs, estàs com una truja. Em deixaràs tota la casa plena d'esbufecs.

BOŻENA: Gràcies, ho veig a la teva mirada, però almenys hauries pogut remugar amb menyspreu que estic com una truja i que no hauria de passejar-me tan descaradament pel camp de visió dels demés. Tenen dret a triar els motius pels quals vomitar.

Aprofitant que la Halina està enfeinada encenent una torxa de querosè, la Petita Noieta Metàl-lica, que va donant voltes per tot arreu buscant coses per destrossar o arrencar, li agafa la revista $i$ com qui no vol la cosa comença a llegir-la.

PETITA NOIETA METÀL·LICA: La Truja Grassa de l'Horòscop pot esperar-se pel mes d'abril passat unes sorpreses d'allò més agradables. Al Dia tindran un nou tipus de mortadel-la barata, el "pernil de pollastre a l'antiga", composició: aigua, pell de porc, sabó rentavaixelles, líquid neteja-parabrises, aigua (al 97\%), gelatina, condiments; i un nou tipus de nata caducada, "Només un parell de dies", composició: aigua, gelatina, colorant blanc, 
“Transfer” XV: 1-2 (2020), pp. 502-561. ISSN: 1886-554

espessidor, anti-espessidor, descalcificador, desintoxicant, cultura viva de salmonel-losi. Allò que no es menjaran els altres, acompanya-ho tu amb allò que no es beuran els altres. Accepta't tal com ets d'una vegada per totes i canvia completament. Per aconseguir-ho surt molt de casa i passeja, perquè com diu aquí a la Truja de l'Horòscop, estàs com una truja, però no surtis i no passegis, especialment pel camp de visió dels altres: tenen dret a vomitar per millors motius.

Torna a deixar la revista com inadvertida per les altres. La Bożena clava una mirada plena d'interès a la revista amb un interès difícil d'amagar, però sense atrevir-se a engrapar-la.

BOŻENA: Oh, quina revista més txula, NO ÉS PER TU.

HALINA: I tant, NO ÉS PER NOSALTRES.

BOŻENA: Que maca.

HALINA: Me l'he comprat avui al container de reciclatge de paper. Una super-oferta: gratis i amb la solució dels mots encreuats. Una agradable sorpresa, com si jo tingués el cap per posar-me a fer mots encreuats!

BOŻENA: Jo, des de que en veritat des de sempre em dedico a l'ofici d'especialista en retirar impureses sanitàries en espais propis privats, no tinc gens de temps per a aquestes coses. No és una feina exigent, però sí cansada i poc satisfactòria.

HALINA: Ho entenc perfectament. Jo com a especialista en el transport de palets de mercaderies amunt i avall del super a través del clàssic mètode físic, m'he d'aixecar abans de posar-me a dormir i torno de la feina després d'haver-me aixecat altre cop per anar-hi. No obstant, a la falta de futur m'han d'ascendir a manager de còmput electrònic del pes real dels objectes del sector de fruites i verdures i penso: perquè no provar-ho? 
“Transfer” XV: 1-2 (2020), pp. 502-561. ISSN: 1886-554

BOŻENA: Oh i tant que sí, qui millor que tu? Llengües: estrangeres, experiència com a agent de repartiment directe i manual de correu comercial, ambaixadora del perfum "Vella Bruixa" a Polònia fent promoció directa a autobusos i tramvies amb una nota dominant de suor, secundada per delicats ecos de mesc, naftalina i sopa de fa uns quants dies.

HALINA (voltant per la cuina $i$ realitzant diverses accions, tan professionals com mancades de sentit): I jo que ja començo a pensar: que arribin ja les vacances que no tindré. Llegeixo, llegeixo i finalment m'he decidit. No se'n parli més, aquest any tornarem a no anar de vacances.

BOŻENA: Què dius ara?

HALINA: Com ho sents. Tornarem a no anar-hi.

BOŻENA: I a on no anireu?

HALINA: Enlloc.

BOŻENA: I què tal un altre lloc? Nosaltres aquest any no anirem al mar. Déu meu, és massa car per nosaltres! No tenim diners per això! A més a més estic com una truja i no hauria de passejar-me tan descaradament pel camp de visió dels demés.

HALINA: Ja ho crec i tant.

BOŻENA: Pel camí tampoc ens aturarem a Les Eugues, on viu la meva cosina... I des d'allà directament tampoc anirem enlloc.

HALINA: Llavors segur que ens hi trobem. Ja tens el número de mòbil que no tinc. Enlloc, entranyable enlloc, tots els meus records provenen d'allà. Tot i que des de fa un parell d'anys està que no s'hi cap, no es pot ni passar, jo mateixa hi tinc el cunyat, la 
“Transfer” XV: 1-2 (2020), pp. 502-561. ISSN: 1886-554

cunyada, el meu germà i la seva dona, l'oncle, la cosina, la germana...

BOŻENA: Oh que s'està fosc aquí! Oh quina estretor!

HALINA (canvia de lloc enèrgicament la cadira de rodes de la Velleta, que la tapa i li impedeix conversar, seguir el programa de la tele i grapejar la revista simultàniament): El pare de vidre, la mare de cristall. Mama, si et penses que ja ets transparent, doncs no, segueixes sense ser-ho. I tu, marxant cap a l'habitació que no tens.

PETITA NOIETA METÀL·LICA: Doncs em sembla que ja hi sóc, però espera que ho comprovo. Hop hop! Hop hop! On sóc? Aquí. Ja, tal com em pensava.

La Petita Noieta Metàllica, altre cop inadvertida per les altres, arreplega la revista.

PETITA NOIETA METÀL LICA: Al contrari que als apartaments projectats d'una forma moderna, en els quals els membres de la família es passen hores cridant-se en va els uns als altres pels espaiosos corredors, halls i habitacions individuals, esforçant-se a arribar allà on ells mateixos es troben, ja no diguem els seus éssers estimats; aquest habitacle claustrofòbicament estret, dóna la impressió de no ser molt gran, i és precisament aquí que una respectable família de diferents generacions dorm conjuntament, menja, evacua, viu, no dorm, va canviant de costat, vomita i té diarrea, no viu i mor, sense haver de buscar-se gens ni mica, sinó tot al contrari: Sempre i en tot moment trobant-se aquí.

Aquest efecte l'aconsegueixen amb un truc arquitectònic molt senzill, han dividit el pis de tal forma que l'habitació que la Petita Noieta Metàl-lica no té, la santa calma que l'ensopida iaia invàlida no té i els nervis de la Halina (que té 51 anys) s'encabeixin perfectament en aquest mateix espai únic, on tot el sant dia es van tirant en cara la calma, vull dir la cambra que no tenen. 
“Transfer” XV: 1-2 (2020), pp. 502-561. ISSN: 1886-554

Resulta difícil de creure que a part d'elles mateixes s'hi hagi pogut ficar tota una col-lecció de mobles originals dels anys setanta (placa de feltre). Amb els anys la seva superfície ha anat quedant desllustrada pam a pam, guixada arreu de gargots infantils; i una barrija-barreja de productes d'alimentació, begudes alcohòliques i excrecions fisiològiques creen sobre el joc de sofà i butaques estil "Mieszko I" un palimpsest extraordinari estilitzat a la manera d'una porqueria d'allò més ordinària. Els cantells del paper de les parets estan humits i gastats, els fongs de la paret, que van tapar amb un kilim, han desaparegut del tot. Una capsa buida de torró de cacauet, un quadre fet amb una tapa de bombonera marca "Solidarnosc", una cinta de plàstic clavada a un test de firodendron, peles de patata enjogassades aquí i allà, ossets de pollastre, esponjós, entranyable borró, l'anuari del diari gratuït Metro, un tub de pasta de dents tirat "com qui no vol la cosa", pots de quefir, no és que uns brètols hagin bolcat el cubell de les escombraries, sinó que...

HALINA (irritada, arrencant-li la revista i deixant-la novament a un lloc segur de la taula): No calla mai!

PETITA NOIETA METÀL·LICA: Estic a la meva habitació que no tinc! 
“Transfer” XV: 1-2 (2020), pp. 502-561. ISSN: 1886-554

\section{ESCENA 4}

La Halina és a la cuina, remena entre les seves olles. La Noieta Metàl-lica empeny la cadira de rodes de la Velleta i després es posa a donar voltes al televisor tot saltant àgilment al darrera de la cadira fins que aquesta es tomba: en aquest punt poden saltar tot de píndoles amagades a la manta com les boles d'un joc de pinball, i no podent tornar a posar l'àvia en posició vertical, la llança a la catifa. Segueix per uns instants donant voltes com si busqués alguna ocupació perduda i seguidament comença a dibuixar amb una vareta sobre el vernís dels mobles. La Velleta, tombada en posició horitzontal, fa trenes o teixeix amb agulles una màniga de jersei de 10 metres. Llavors deixa la seva feina i arrapant-se desesperadament als coixins s'esforça per aixecar-se. La Bożena, a la seva butaca, cada vegada s'acosta més decididament al No és per tu fins que amb mà tremolosa l'agafa i gira algunes pàgines, al principi tímidament, però finalment es posa a llegir cada vegada més decidida i fins i tot fa comentaris.

BOŻENA: El psico-test encara està per fer.

HALINA: Veus que bé.

BOŻENA: El faré, perquè malaguanyat si no. Tu què ets? una excursionista espontània, una casolana termofíllica, una sexy vampiressa, una addicta al treball desbordada, una instigadora fantasiosa, una incorregible viatgera, una truja panxuda, una perca congelada d'oferta del Carrefour...

HALINA (fregant-se les mans al jersei i llançant-li una mirada per sobre l'espatlla): Jo una incorregible viatgera.

BOŻENA: Oh i tant, jo igual. Incorregible viatgera: totes les respostes A. Però hi posaré una B per dissimular. Ja està! 
“Transfer” XV: 1-2 (2020), pp. 502-561. ISSN: 1886-554

HALINA: El meu posa'l d'un altre color, per no confondre'ns. Sembla cosa de babaus, però com l'encerta...

BOŻENA: L'encerta com res! Te'n recordes quan no vaig estar a França i que mai no hi posaré els peus? Truita a la francesa i baguette, allà s'alimenten bàsicament d'això i mira que és una barra de pa normal i corrent o pitjor. La silueta monumental d'aquella torre tan famosa, que sembla molt alta, molt alta, a la foto del diari és més petita que el meu dit.

HALINA: Això no és res, nosaltres no vam anar a Itàlia. Però no em va agradar GENS NI MICA no haver-hi anat. Ni pensar-hi! Per menjar, res d'especial. Col llombarda, mortadel-la, lluç a la romana, napolitanes, aquella seva famosa pizza congelada d'oferta del Lidl i a més amb verdet, t'imagines? Me la vaig menjar, perquè no la llençaré, però per a pair... Està sobreplubicitada Itàlia, així que al final vam anar a petar a Porto. A més, no hi havia sentit d'anar-hi, perquè el Papa ja no va esdevenir home, sinó que va ser alemany. ${ }^{1}$ Que bé, no haver-hi estat i no haver fet fotos, així no te les he d'ensenyar.

TRISTA VELLETA (aconsegueix tornar a la cadira de rodes, que grinyola): Els alemanys van entrar a Varsòvia...

PETITA NOIETA METÀL·LICA: Els alemanys, ja sé, són aquells que tota l'estona fan yolororihuuu!

HALINA (instructivament): Els alemanys són aquells que viuen a la RFA i no renten les bosses, sinó que les llencen i dels pots de quefir ja ni en parlem, és curiós. No sé pas com deuen fer gelatina amb la pell de pollastre que sobra. Més endavant, quan vingui la Segona Guerra Mundial, vindran cap aquí.

${ }^{1}$ Referència al títol de la pel-lícula "Karol, l’home que es convertí en Papa" (2005), de Giacomo Battiato, basada en la vida de Karol Wojtyła, Papa Joan Pau II, rellevat en el càrrec per Joseph Ratzinger, Papa Benedicte XVI. 
“Transfer” XV: 1-2 (2020), pp. 502-561. ISSN: 1886-554

La Bożena es treu de ves a saber on un àlbum de fotos tot bavós $i$ socarrat.

HALINA: Que grassa! Que poc bronzejada! Ho ho ho. No sé com has cabut a la foto.

BOŻENA: Aquí no hi vam estar. I aquí també no hi vam estar. I aquests d'aquí no som nosaltres. Si tingués aquest àlbum, te'l ensenyaria.

Amb la mateixa promptitud amaga l'àlbum.

HALINA: Aquests sí que se la passen bé. A no viure la vida.

BOŻENA: I doncs què? D'una manera o altra tothom vol no viure. 
“Transfer” XV: 1-2 (2020), pp. 502-561. ISSN: 1886-554

\section{ESCENA 5}

Continua l'estagnació. La Halina i la Bożena, absortes en els seus pensaments amb els braços reflexivament plegats sobre les panxes. Grinyol de la cadira de rodes de la velleta, grinyol del clau de la Petita Noieta Metàlllica sobre el vernís dels mobles o escarritx $i$ espurneig dels cables tallats per ella.

HALINA: Vols menjar alguna cosa? He llegit aquí una recepta genial: samfaina. Aquella mortadel-la prehistòrica del Tesco, enlloc de llençar-la, li treus el verdet, si ja està llefiscosa la fregeixes una mica i després ho talles a llesques de pernil de Parma. Agafes crema per untar sabor formatge i el ratlles de parmesà, ha de tenir una consistència que recordi a una plastilina tan grapejada que ja no serveixi per res. Ho tires a la sopa de xampinyons de la setmana passada. Llavors hauria d'agafar un to irisat.

BOŻENA: I d'on trec la sopa de xampinyons?

HALINA: La prepares la setmana passada.

BOŻENA: Sí que és fàcil. I aquestes coses ràncies i amargues a la superfície, què són?

HALINA: Són pinyons.

BOŻENA: Pinyons? Qui tipus són... pinyons?

HALINA: Jo també és la primera vegada que ho sento. Però són molt bons, s'assemblen molt als cacauets d'oferta i de fet ho són. Saps què has de fer, si no te'ls menges, no se sent gens el ranci. També hi pots afegir pa sec, les venes de la carn, ossos... No ho llencis, ho fregeixes en llard, ho bulls amb potes de pollastre, ho passes pel turmix, ho tornes a fregir, no ho llencis, ho sales bé i ho escalfes en pots de quefir, ho reescalfes, ho refregeixes, t'ho 
“Transfer” XV: 1-2 (2020), pp. 502-561. ISSN: 1886-554

menges, i si comença a treure escuma, doncs ho vomites i a vegades ni ho vomites i llestos. Ara es riuen de mi, però la propera vegada que vingui la Segona Guerra Mundial, endraparan d'una manera que les orelles els hi tremolaran.

BOŻENA: Gràcies, tan grassa i encara té un budell buit. Engoleix d'una manera que les orelles li tremolen. Endrapa, endrapa, truja, endrapa que porta sèsam. Jo encara ho serviria amb el culet del pa.

HALINA: Perdona que t'ho expliqui tot per res, però és que m'ho he menjat tot, abans que es fes malbé.

BOŻENA: Ja... Doncs res. Me'n vaig volant, demà m'he d'aixecar abans de posar-me a dormir.

HALINA: Jo també, quan torni molt més tard de l'hora que m'he tornat a aixecar, segur que encara hauré d'eixugar un bassal amb paper de diari.

BOŻENA: Ja no sóc aquí.

HALINA: Per a qualsevol cosa, jo tampoc hi sóc.

En aquest moment la Petita Noieta Metàlllica inclinant-se torna a agafar la revista femenina i comença a llegir.

PETITA NOIETA METÀL-LICA: L'efecte de caos aparent i casualitat de bric-à-brac en aquest antic, però preciós apartament, completament devastat, s'ha aconseguit a través d'un verdader caos i per casualitat. Present a tot arreu, l'abocador d'il-lusions recorda un autèntic abocador, que és el que en essència és. L'opinió del nostre expert, estilista d'interiors: Aquesta miserable cort de porcs és un vell apartament d'abans de la guerra veritablement encantador. No obstant, a pesar d'haver-s'hi practicat, més o menys des de la guerra, una conseqüent manca de 
“Transfer” XV: 1-2 (2020), pp. 502-561. ISSN: 1886-554

reformes, segueix mancant-hi la netedat, ventilació i espai tan de moda des de fa vàries temporades. Plantegem dues possibles solucions a aquest desagradable malson.

La primera, bastant costosa, seria transformar aquesta cambra en un celler de vi (però sense guardar-hi, per exemple, el material d'esquí o snowboard: humitat!) i traslladar-se a un apartament de luxe. Les lleixes i els penjadors en bon estat així com la seva enginyosa distribució poden possibilitar que algunes ampolles verdaderament gustoses hi puguin ésser tingudes!

La segona, econòmica: Els membres de la família es maten entre si i retornen reencarnats de manera més profitosa o, millor, simplement no neixen mai i no viuen i així és millor per a tots ells i sobretot per tots els altres tots. El millor seria enderrocar l'edifici sencer (estaria bé fer-ho durant la guerra, més tard hi poden haver problemes) i edificar sobre les runes un elegant bloc de pisos; que la gent normal hi compri pisos, que hi posin un sofà-llit d'Ikea RIKKA, una tauleta d'Ikea STAKKA, un gerro ROSTE, flors HAMMA, aigua per a les flors LIKKE, aire per a l'habitació GRETTA, a si mateixos MATTEX i que ho paguin tot a crèdit durant quaranta anys, que passin per aquí a fer una becaina després de la feina, a rentar-se el pompis i sant tornem-hi. 